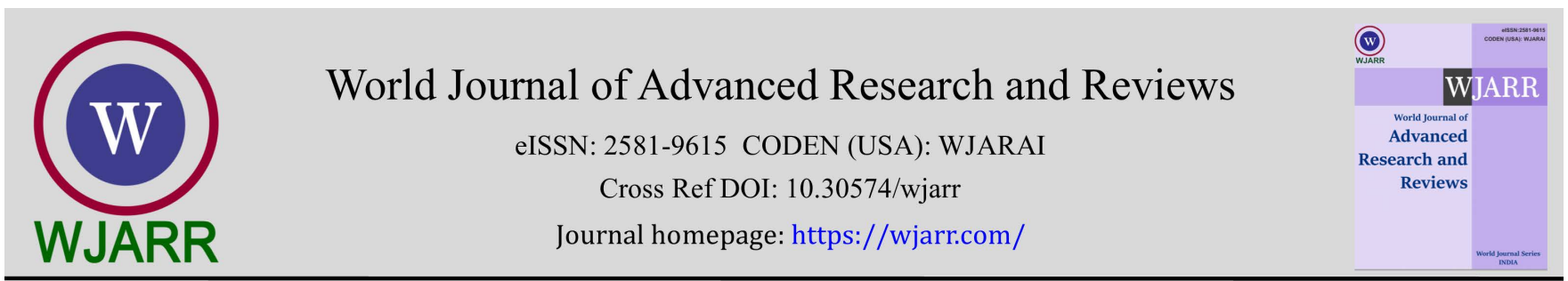

(RESEARCH ARTiClE)

Check for updates

\title{
Factors affecting the selection of instructional materials in the teaching and learning of basic science in secondary schools, Imo State Nigeria
}

Mbaegbu Nnamdi O 1, *, Unamma Anthony $\mathrm{O}^{2}$, Okorie Ikechukwu D 3, Ohuakanwa Onyedimma S 4, Odupute Colman N 5, Zubair Abdulkarim I 6, Chima Onyekachi Chris 7, Ihunda Moses 8, Mbagwu Geraldine C 9, Opara Emmanuel C ${ }^{10}$ and Akpelu Alvana U 10

\author{
1 Surveillance and Epidemiology Department, Nigeria Centre for Disease Control, Abuja, Nigeria \\ 2 Department of Curriculum Studies, Imo State University, Owerri, Imo State, Nigeria \\ ${ }^{3}$ Faculty of Vocational Technical Education. Department of Business Education. University of Nigeria Nsukka \\ ${ }^{4}$ Department of Vocational Teacher Education University of Nigeria Nsukka. \\ ${ }^{5}$ Department of Radiology, Kogi State University Teaching Hospital, Dekina, Kogi State, Nigeria \\ ${ }^{6}$ Department of Drug development and Research, Nigerian Institute for Trypanosomiasis Research, Birnin-Kebbi, Kebbi \\ State, Nigeria \\ ${ }^{7}$ Department of Educational Foundations, University of Lagos, Akoka, Lagos State, Nigeria \\ ${ }^{8}$ Department of Accounting, Ignatius Ajuru University of Education, Rumuolumeni, Port-Harcourt, Rivers State, Nigeria \\ 9 Department of Public Health, Federal University of Technology, Owerri, Imo State \\ ${ }^{10}$ Department of Environmental Health, School of Health, Amaigbo, Owerri, Imo State, Nigeria.
}

World Journal of Advanced Research and Reviews, 2021, 11(03), 399-404

Publication history: Received on 13 August 2021; revised on 23 September 2021; accepted on 25 September 2021

Article DOI: https://doi.org/10.30574/wjarr.2021.11.3.0449

\begin{abstract}
This study was conducted to assess the factors affecting the selection of instructional materials in the teaching and learning of basic science in secondary schools, Imo State Nigeria. The study employed a descriptive survey design to find out how factors affecting the selection of instructional materials in the teaching and learning of basic science in public secondary schools in Owerri Municipal Council, Imo State. Two hundred (200) respondents comprising teachers and students from seven (7) public secondary schools in the council were interviewed using a modified five-point Likert instrument (questionnaire). The data collected were coded into SPSS and analyzed with descriptive statistics. The results showed that 103 persons strongly reported they don't have availability instructional materials, 68 persons agreed that unfavourable time allocation affects instructional materials used by teachers to develop lesson plan, 69 persons strongly agreed that lack of skills is one of the factors affect instructional materials used in the teaching and learning of basic science in secondary schools. Also, 148 persons strongly agreed that instructional materials should be made available in schools and teachers should be encouraged in using materials during teaching. Then, lack of instructional materials/facilities and non-utilization were among the major causes of poor performance of students in basic science in Owerri Municipal Council. In conclusion, it was understood that non availability of instructional materials, unfavourable time allocation, lack of skills, lack of facilities like basic science laboratory were major factors affect teachers, school administrators and government in teaching and learning of the basic science. Therefore, Government or public school authorities should help to provide instructional materials such as modern textbooks, charts, posters, computers, flip chart, and audio recordings, because basic science in secondary schools cannot be adequate learned without instructional materials.
\end{abstract}

Keywords: Factors; Instructional Materials; Science; Laboratory; Learning and Teaching

*Corresponding author: Mbaegbu, Nnamdi Okwudiri ; E-mail:mbaegbunnamdi@gmail.com

Surveillance and Epidemiology Department, Nigeria Centre for Disease Control, Abuja, Nigeria.

Copyright (C) 2021 Author(s) retain the copyright of this article. This article is published under the terms of the Creative Commons Attribution Liscense 4.0. 


\section{Introduction}

Science education is the cornerstone of any nation and has remained for sometimes a big industry in Nigeria. The development of any country depends on the quality of her science education which also depends among other factors on the professional qualification and occupational competence of the teachers. Science education is a vital tool for the integration of an individual into the larger society so that the person can achieve self-realization, develop national consciousness promote unity and strive for socio-economic, political, scientific, cultural and technological progress [1].

Previously, basic science was known as Integrated Science which is the first form of science a child comes across at the secondary school level. Basic science is a core subject in the National curriculum at the upper basic level [2]. All students from upper basic I-III classes in Nigeria secondary education must offer and study the subject basic science. Basic science is considered the bedrock of all science subjects at the senior secondary school (SSS) level. According to Oludipe [3], the subject prepares students at the upper basic level for the study of core science subjects (biology, chemistry and physics) at the senior secondary school level. That is why Oludipe (2012) further emphasised that for a student to be able to study single science subjects at the post-secondary level successfully; such a student has to be well grounded in basic science at the upper basic level. Based on this, it is generally taught as a single science subject, until in the SSS level, and then split into specialized science subjects (biology, chemistry and physics). It is expected that those students who achieve well in basic science should be given the opportunity to study the separate science subjects at the SSS level.

Nigeria's aspiration as a developing country is for a positive advancement in science and technology. It is believed that such advancement will help a country like Nigeria to compete favorably with the so-called high income countries of the world with this positive advancement in science and technology cannot be achieved without effective and efficient basic science education; hence the importance of basic science education in science and technology cannot be over stressed [4].

It is also needed by those who will study natural science subjects in the senior secondary schools as a foundation for the pursuit of life careers in natural sciences, health/medical sciences, technological and engineering related fields. With all the importance of basic science in the Nigerian educational system, for many years, basic science has witnessed a flood of persistent high failure rate in public examinations. This unpleasant situation have given both the Nigerian government and well meaning citizens a source of concern. Various examination analyses have tried to identify factors which could contribute to the observed poor performance. Indeed, the general consensus using Federal Ministry of Education report of 2010 is that the poor performance in basic science resulted from remarkablel ack of well organized human resources, instructional materials and facilities in teaching and learning of basic science at the junior secondary education level [5].

For effective teaching/learning of any subject more especially those requiring theoretical and practical dimensions like basic science, certain materials are required; such materials are referred to as instructional materials. Instructional materials represent all the alternative channels of communication which teachers can use to compress and represent materials in a more vivid form to the subjects. According to Dike [6], instructional materials are set of materials which classroom teacher can use to extend the range of vicarious experiences to his learners, hence instructional materials will enable the learners argument the learning process by providing extended experiences.

Instructional materials can be classified into two board categories namely; standard and locally produced instructional materials. The standard materials refer to conventional or sophisticated materials and equipment manufactured or produced by a recognized company or organization, while the locally produced instructional materials refer to materials produced and utilized by teachers using alternative material resources to facilitate effective teaching and learning, [7].

Instructional material is used efficiently and actively to facilitate the teaching and learning process in most of the high income countries. However, the situation is not good in most of the low and medium income countries such as Nigeria. Firstly, only the lower quality and the less quantity of instructional materials are provided to schools; in this way, the availability of the instructional material is very less. Secondly, teachers are not trained properly for using these instructional materials. Thirdly, teachers do not take interest in using the instructional materials. The government is spending a huge amount of money in the educational sector; however, the quality of education is very low. There are many factors that are responsible for this sorry state of affairs. Less availability and deficient use of instructional materials is one of them, therefore the researcher observed that instructional materials for basic science teaching are unavailability, costly and out of reach for many secondary schools more especially at the rural areas and even the ones available cannot be used by the teachers due to so many other factors. Therefore, the factors affecting the selection of instructional materials in the teaching and learning of basic science in secondary schools level need to give attention. 


\section{Material and methods}

A descriptive survey design was adopted in this study to determine the factors affecting the selection of instructional materials in the teaching and learning of basic science in secondary schools level in Owerri Municipal Council, Imo State, Nigeria.

The area of study was Owerri Municipal Council which is the capital city of Imo State, Nigeria. It is one of the 27 local government areas of Imo state, located on the South-Eastern part of Nigeria.

Owerri Municipal Council has a land mass of $24.88 \mathrm{~km} 2$ with a plain terrain of $19.14 \mathrm{Km}^{2}$ and wet land of $5.47 \mathrm{Km}^{2}$. She is bounded on the North by Amakohia, on the North east by Uratta, on the East by Egbu, on the South-East by Naze, on the South by Nekede and on the North-West by Irete. The vegetation is tropical rain forest although some parts consist of Guinea Savanna forest. The mean annual rainfall is the council is between $2,250 \mathrm{~mm}$ and $2,500 \mathrm{~mm}$, while the mean annual temperature is $25^{\circ} \mathrm{C}$ to $27^{\circ} \mathrm{C}$. the relative humidity is around $80 \%$.

The population of the study consists of all the staff and students of the public secondary schools in Owerri Municipal Council Imo State, Nigeria. The schools and their respective populations are listed below:

Table 1 Population of Teachers and Students in the study area

\begin{tabular}{|l|l|c|c|}
\hline S/N & Item Statements & Teachers & Students \\
\hline 1 & Boys'Model Secondary School, New Owerri & 90 & 1,366 \\
\hline 2 & Comprehensive Development Secondary School, Owerri & 103 & 3,377 \\
\hline 3 & Emmanuel College, Owerri & 74 & 1,183 \\
\hline 4 & Government Secondary School Owerri & 130 & 3,673 \\
\hline 5 & Government Technical College, Owerri & 117 & 1,994 \\
\hline 6 & Ikenegbu Girls' Secondary School, Owerri & 133 & 4,109 \\
\hline 7 & Urban Development Secondary school, Owerri & 81 & 1,849 \\
\hline \multicolumn{2}{|c|}{ Source: Secondary Education Management Board (2018/2019) [8] } & 17,551 \\
\hline
\end{tabular}

Based on the population of the selected schools; ten (10) respondents basic science teachers were randomly selected from each of the seven secondary schools studied. Similarly, $10 \%$ of students' populations were randomly selected from each secondary school studied. The table below shows the sampled population:

Table 2 Population of selected Teachers and Students in the study area

\begin{tabular}{|l|l|c|c|}
\hline S/N & Item Statements & Teachers & Students \\
\hline 1 & Boys' Model Secondary School, New Owerri & 10 & 14 \\
\hline 2 & Comprehensive Development Secondary School, Owerri & 10 & 33 \\
\hline 3 & Emmanuel College, Owerri & 10 & 11 \\
\hline 4 & Government Secondary School Owerri & 10 & 36 \\
\hline 5 & Government Technical College, Owerri & 10 & 16 \\
\hline 6 & Ikenegbu Girls' Secondary School, Owerri & 10 & 11 \\
\hline 7 & Urban Development Secondary school, Owerri & 10 & 9 \\
\hline & Total & 70 & 130 \\
\hline
\end{tabular}

Source, [8]

The instrument used for data collection was questionnaire and it consists of questions on modified four (4) point liket type scales of Strongly Agree (SA), Agree (A), Disagree (D) and Strongly Disagree (SD). A total of two hundred (200) copies were distributed accordingly. The respondents filled the questionnaire and they were collected on the spot by 
the researcher to avoid loss on transit, and also to ensure that selected respondents were responsible for the data. Data collected were coded into SPSS and analyzed with descriptive statistics.

\section{Results}

Table 1 shows the factors selecting instructional materials in the teaching and learn of basic science in secondary schools; 103 persons strongly agreed that non availability instructional materials determine the degree to which they are consisting with the goals, 81 persons agreed, 14 disagreed and 2 strongly disagreed. Unfavourable time allocation affects instructional materials which could have help to ensure a thoughtful and effective process in learning; 59 persons strongly agreed, 68 agreed, 33 persons disagreed and 40 persons strongly disagreed. Problems of lack of skills among teachers in order to impact the knowledge of accurate science content; 69 persons strongly agreed, 114 agreed, 6 persons disagreed and 11 persons strongly disagreed. Lack of facilities like basic science laboratory affects the understanding of basic science; 126 persons strongly agreed, 45 agreed, nobody disagreed and 29 persons strongly disagreed. Adequate time and opportunity for abilities and understanding of the subject matter concept; 85 persons strongly agreed, 64 agreed, 23 persons disagreed and 28 persons strongly disagreed. From the analyzed results it was observed that the mean to all the item statements were greater than 2.5 which show a statistical significant responses from the respondents to the research question on the factors for selecting instructional materials in the teaching and learning of basic science in secondary schools in Owerri Municipal Council.

Table 3 Factor Selecting Instructional Materials in the Teaching and Learn of Basic Science in Secondary Schools.

\begin{tabular}{|l|l|l|l|l|l|l|l|l|}
\hline S/N & Item Statement & SA & A & D & SD & EFX & N \\
\hline 1. & $\begin{array}{l}\text { Non availability of the instructional } \\
\text { materials }\end{array}$ & 103 & 81 & 14 & 2 & 685 & 200 & 3.4 \\
\hline 2. & Unfavourable time allocation & 59 & 68 & 33 & 40 & 546 & 200 & 2.7 \\
\hline 3. & Lack of skills & 69 & 114 & 6 & 11 & 641 & 200 & 3.2 \\
\hline 4. & $\begin{array}{l}\text { Lack of facilities like basic science } \\
\text { laboratory }\end{array}$ & 126 & 45 & - & 29 & 668 & 200 & 3.3 \\
\hline 5. & $\begin{array}{l}\text { Adequate time and opportunity for abilities } \\
\text { and understanding of the subject matter } \\
\text { concept }\end{array}$ & 85 & 64 & 23 & 28 & 606 & 200 & 3.3 \\
\hline
\end{tabular}

The table 2 showed the strategies that can be used to enhance basic science teachers to utilize instructional materials in the teaching and learning of basic science in secondary schools; 148 persons strongly agreed that instructional materials should be made available in schools and teachers should encouraged to use them during teaching, 40 persons agreed, nobody disagreed and 12 strongly disagreed. Establish instructional materials centres and laboratory in all schools where instructional material are kept; 151 persons strongly agreed, 38 agreed, 10 persons disagreed and 1 persons strongly disagreed. Government should employ basic science teachers who are professionally trained; 139 persons strongly agreed, 45 agreed, nobody disagreed and 16 strongly disagreed. School authorities should insist on the use of various teaching methods which lead to acquisition of skills by students in basic science; 131 persons strongly agreed, 49 agreed, nobody disagreed and 20 strongly disagreed. Incentive should be given to teacher who utilizes instructional materials during teaching; 62 strongly agreed, 105 agreed, 20 disagreed and 13 strongly disagreed. The item statements are statistically significant as their means scores were above 2.5 and also supported by the cluster mean 3.5. This means that the problems that are associated with the availability and utilization of instructional materials in the teaching and learning of basic science in secondary schools. 
Table 4 Strategies that can be used to Enhance Basic Science Teachers to Utilize Instructional Materials in the Teaching and Learning of Basic Science in Secondary Schools

\begin{tabular}{|l|l|l|l|l|l|l|l|l|}
\hline S/N & Item Statements & SA & A & D & SD & EFX & N & $\mathbf{X}$ \\
\hline 1 & $\begin{array}{l}\text { Instructional materials should be made } \\
\text { available in schools and teachers should } \\
\text { encourage to use them during teaching }\end{array}$ & 148 & 40 & 12 & - & 736 & 200 & 3.7 \\
\hline 2 & $\begin{array}{l}\text { Establish instructional materials centres and } \\
\text { laboratory in all schools where instructional } \\
\text { material are kept. }\end{array}$ & $\begin{array}{l}\text { Government should employ basic science } \\
\text { teachers who are professionally trained. }\end{array}$ & 38 & 10 & 1 & 739 & 200 & 3.7 \\
\hline 3 & $\begin{array}{l}\text { School authorities should insist on the use of } \\
\text { various teaching methods which lead to } \\
\text { acquisition of skills by students in basic science. }\end{array}$ & 131 & 49 & - & 20 & 691 & 200 & 3.5 \\
\hline 5 & $\begin{array}{l}\text { Incentive should be give to teacher who utilize } \\
\text { instructional materials during teaching. }\end{array}$ & 62 & 105 & 20 & 13 & 616 & 200 & 3.1 \\
\hline & \begin{tabular}{l} 
Cluster mean \\
\hline
\end{tabular}
\end{tabular}

Strong agree (SA), Agree (A), Disagree (D), Strong disagree (SD), Summation of fx (EFX), Frequency (N) Mean (X)

\section{Discussion}

The findings of this research reveal the need of instructional materials used in teaching by teachers and for students to learn basic science in secondary schools. The instructional materials are used to develop lesson plan, to assess the knowledge of their students, to offer the teachers some insight into the methods of creating examinations and to provide innovative and creative ways to assess students' performance [8]. This implies that utilization of instructional materials in the teaching and learning of basic science in secondary schools are of great importance to both the teacher and their students. The above explanation was supported by Dahar [9], who stated that instructional materials are highly important for teaching, especially for inexperienced teachers.

The findings of this study agreed with Abubakar [10] and Abimbade [11] who observed that problems associated with utilization of instructional materials among basic science teachers were non availability, unfavourable time allocation, lack of skills, lack of facilities like basic science laboratory that hinders the use of instructional materials and inability to appreciate the need for using instructional materials by the basic science teachers are the problems that are associated with the utilization of instructional materials by the basic science of teacher in secondary schools in Owerri Municipal Council.

Mbaegbu, [8] opined that the strategies to be used to enhance basic science teacher's utilization of instructional materials in the teaching and learning of basic Science in Secondary Schools focused on availability of instructional materials, establishment of instructional materials centres and laboratory, employment of professional trained basic science teachers by Government. Yusuf [12] stated that there are strategies which can be utilized to enhance the availability and utilization of instructional materials among basic science teachers and other teachers in teaching and learning of basic science, in secondary schools.

\section{Conclusion}

The findings of this study showed that there are some factors responsible in selecting instructional materials in the teaching and learning of basic science in secondary schools, Imo State Nigeria and such factors include; non availability of instructional materials, unfavourable time allocation, lack of skills, lack of facilities like basic science laboratory.

\section{Recommendations}

In line with the findings of the study, the following recommendations were made; 
Government or public schools authorities should help to provide instructional materials such as modern textbooks, charts, posters, computers, flip chart, and audio recordings, because basic science in secondary schools cannot be adequate learned without instructional materials.

Instructional materials should be available for teaching in public schools and private schools than though teachers in public schools are more favorably disposed to the use of instructional materials than teachers in private school.

\section{Compliance with ethical standards}

\section{Acknowledgments}

The authors are grateful to teachers of secondary schools in Owerri Municipal Council who assisted and permitted in administering questionnaire and collection of data for this study. The authors express profound appreciation to the Principals of the schools that participated for their cooperation in providing enabling environment for the research work.

\section{Disclosure of conflict of interest}

All authors of this article report no conflicts of interest throughout the work.

\section{References}

[1] Ijanaki, MO Teacher Education for National Reconstruction. Benin City: Confluence Journal of Education 1 (1): Rainbow House Publishers. 2004.

[2] Kim, C Poor lacking choice of sciences. Retrieved 2021, April 4th from http://news.bbc.co.uk/l/hi/education/72455 29.stm. 2008.

[3] Oludipe, D I Gender difference in Nigerian Junior Secondary Students' academic achievement in Basic science. Journal of Educational and Social Research, 2012; 2 (1): 93-99.

[4] Federal Republic Nigeria. National Policy on Education, Lagos: Nigerian Educational Research and Development Council. 2004

[5] Badru, A K Students Performance in Health Science as Correlate of their Performance in other Basic science, in M.G Akade (ed) Refocusing Research in Science Technology and Health Science Education in Nigeria: Processings of $45^{\text {th }}$ Annual Conference of the Science Teachers Association of Nigeria (STAN): Ibadan Heinemenn. 2004.

[6] Dike, HI Alternative Teaching Approach for Social Studies Port Harcourt: Capuc Publishers. 2002; 6-15

[7] Wikianwers. Meaning of instructional materials. Available at http://www.en.wikianswers.org/wiki. Instructional Material. 2011.

[8] Mbaegbu, NO; Unamma, AO; Ede, AO; Okorie, ID; Ohuakanwa, OS; Odupute, CN; Zubair, AI; Chima, OC; Ihunda, M; Mbagwu, GC; Opara, EC and Akpelu, AU Availability and Utilization of Instructional Materials in Teaching and Learning of Basic Science in Secondary Schools in Owerri Municipal Council, Imo State, Nigeria. IOSR Journal of Research and Method in Education (IOSR-JRME). 11(4 Ser. IV), 2021; 45-50. www.iosrjournals.org.

[9] Dahar, MA Effect of Availability and the Use of Instructional Materials on Academic Performance of Students in Punyab (Pal istan): Department of Education, International Islamic University, Islamabad. 2011

[10] Abubakar, IM Educational Technology for Improvement of Teaching and Learning Environment in Nigeria Federal University of Technology, Minna, Niger State: Technology Educational Environment Issues in NATT Nigeria GSS of Teachers of Technology, 15 th NATT Annual National Conference FUTM. 2002.

[11] Abimbade, A. Principles and Practice of Education Technology. Abuja: International Publishers Limited, 2000; $10-13$

[12] Yusuf, M. Problems Associated with the Improvision and Utilization of Instructional Materials for Successful Implementation of Mathematics Curriculum at Junior Secondary School Level: Federal College of Education, Mokwa, Niger State. 2010. 